\title{
NON-RANDOMISED CONTROLLED TRIAL COMPARING THE EFFECTIVENESS OF BIORESORBABLE PLATES VERSUS TITANIUM MINIPLATES IN THE MANAGEMENT OF MANDIBULAR FRACTURES UNDER GENERAL ANAESTHESIA
}

\author{
Maina Bekal1, Brijesh K², Suresha K. R
}

${ }_{1}^{1}$ Assistant Professor, Department of Dentistry, Akash Institute of Medical Sciences and Research Centre.

${ }^{2}$ Assistant Professor, Department of Anaesthesiology, Akash Institute of Medical Sciences and Research Centre.

${ }^{3}$ Professor, Department of Pharmacology, Akash Institute of Medical Sciences and Research Centre.

\begin{tabular}{l}
\hline ABSTRACT \\
BACKGROUND \\
Mandibular fracture treatment includes restoration of anatomic form and function with establishment of occlusion. Different \\
methods are used to provide stable fixation like metallic compression plates, mini plates, locking plates, 3D plates and \\
bioresorbable plates, etc.
\end{tabular}

The present study compared the effectiveness of bioresorbable plates to the conventional titanium miniplates.

\section{MATERIALS AND METHODS}

Non-randomised controlled trial conducted on patients aged between 16 - 56 years of either gender with clinical and radiographical evidence of mandibular fractures requiring open reduction and internal fixation, visiting dental department for the period of one year were enrolled for the study. They were intervened with either Bioresorbable Plates or Titanium Miniplates for the management of mandibular fractures under general anaesthesia. The patients were allotted in 2 groups. Group-I was treated with $2.5 \mathrm{~mm}$ Bioresorbable plates and screws; Group-II was treated with $2.0 \mathrm{~mm}$ Titanium miniplates and screws. Clinical and radiographic outcome parameters such as stability of occlusion, mobility of fracture fragments, need for intermaxillary fixation, wound healing, stability of fixation, displacement of fracture fragments and healing of fracture site were evaluated.

\section{RESULTS}

In Group-I 6 patients showed unstable occlusion, 4 patients showed fracture mobility, 6 patients required intermaxillary fixation, whereas in Group-II only 3 patients had unstable occlusion, none of the patients showed fracture mobility (p < 0.05), only 3 patients required IMF during $1^{\text {st }}$ week post-operatively. There was no abnormality in wound healing/ soft tissue dehiscence and post-operative healing was satisfactory in both the groups.

\section{CONCLUSION}

The use of $2.0 \mathrm{~mm}$ titanium miniplates is a viable and better option as compared to bioresorbable plates for fixation of mandibular fractures. The stability of titanium plates is significantly higher than the bioresorbable plates for early function of mastication.

\section{KEYWORDS}

Mandibular Fracture, Titanium Miniplates, Bioresorbable Plates, General Anaesthesia.

HOW TO CITE THIS ARTICLE: Bekal M, Brijesh K, Suresha KR. Non-randomised controlled trial comparing the effectiveness of bioresorbable plates versus titanium miniplates in the management of mandibular fractures under general anaesthesia. J. Evolution Med. Dent. Sci. 2017;6(90):6286-6291, DOI: 10.14260/jemds/2017/1367

\section{BACKGROUND}

Maxillofacial injuries ranges from isolated injuries involving only one or two components of the facial skeleton to complex facial injuries of the entire facial skeleton. Major causes of mandibular fractures include assaults, falls, motor vehicle accident, work related accidents, dentoalveolar surgery, fracture of edentulous atrophic mandible and pathological fracture. Mandibular fractures occur from both direct and indirect trauma to the head and neck region. ${ }^{1}$ Because of prominent position, mandible is most commonly fractured. Mandibular fracture occurs in common location

'Financial or Other Competing Interest': None.

Submission 18-08-2017, Peer Review 01-11-2017,

Acceptance 08-11-2017, Published 20-11-2017.

Corresponding Author:

Dr. Maina Bekal,

Department of Dentistry,

Akash Institute of Medical Sciences

and Research Centre.

E-mail: drmainabekal@yahoo.com

DOI: $10.14260 /$ jemds $/ 2017 / 1367$ like body (29\%), condyle (26\%), angle (25\%), symphysis (17\%), ramus $(4 \%)$ and coronoid process. ${ }^{2}$ The management aims at restoration of anatomical form and function with particular care to re-establish the occlusion; can be achieved by both closed and open methods. ${ }^{3}$ Many systems for direct fixation have been developed. These range from metallic compression plates, mini plates, locking plates, 3D plates to bioresorbable plates. The advantages of metal plates are its biocompatibility, corrosion resistance and osseointegration. ${ }^{4}$ Metal plates causes discomfort, thermal sensitivity, local macroscopic and microscopic destruction of hard and soft tissue around the plate, also migration of these metal plates can hinder local structural growth and interfere with diagnostic and therapeutic radiation. ${ }^{5,6}$ The shortcomings of metal plates led to development of bioresorbable plates. The disadvantage of the bioresorbable system includes cost, large number of armamentarium and inability to withstand torsional and muscular forces. ${ }^{4}$ The advantage of bioresorbable device includes provision of strength when necessary and then degrades overtime until the load can be safely transferred to the healed bone. In this study, the 
effectiveness of bioresorbable plates are compared to conventional titanium miniplates.

\section{MATERIALS AND METHODS}

This study was initiated after hospital ethics and research committee approval and the written informed consent was obtained from all the patients prior to the enrolment. The patients aged between 16 - 56 years of either gender with clinical and radiographical evidence of mandibular fracture (with or without any associated fracture) requiring open reduction and internal fixation, visiting dental department for the period of one year between January 2016 and December 2016 were enrolled. They were intervened with either Bioresorbable Plates or Titanium Miniplates for the management of mandibular fractures under general anaesthesia. The 9 patients were allotted to Group I and 10 were allotted to Group II.

\section{Group-I}

Patients were treated with $2.5 \mathrm{~mm}$ Bioresorbable plates and screws.

\section{Group-II}

Patients were treated with $2.0 \mathrm{~mm}$ Titanium miniplates and screws.

The exclusion criteria include patients with infected fractures, completely edentulous patients, medically compromised patients with contraindication for open reduction and internal fixation under general anaesthesia (GA).

\section{Study Design}

Non-randomised controlled trial.

\section{Study Procedure}

Under GA depending on the location of fracture, two plates were used for fixation of fractures in the interforaminal region; a single plate was used for fixation of fractures in the body and angle region. Intermaxillary fixation was done before fixation of the fracture. On completion of procedure, intermaxillary fixation was removed.

For Group I patients, $2.5 \mathrm{~mm}$ bioresorbable plate was used. The plate was placed in a water bath at $55^{\circ} \mathrm{C}$ for 1 to 2 minutes, allowing the plate to become soft. The softened plate was then adapted to the mandible across the fracture site. After adequate plate adaptation the screw holes were drilled with $2.3 \mathrm{~mm}$ drill bits, which was followed by tapping. The plates were secured with $2.5 \mathrm{~mm}$ resorbable screws of $8 \mathrm{~mm}$ length. For Group II patients, $2.0 \mathrm{~mm}$ titanium miniplates and $6 \mathrm{~mm} / 8 \mathrm{~mm}$ screws were used respectively. The patients were evaluated for the following parameters pre-operatively during 1st, at the end of 1st week, 6 weeks and 6 months post-operatively clinically.

\section{Outcome Measurements}

Clinical and Radiological parameters were evaluated at the end of 1st week, 6 weeks and 6 months post-operatively. Clinical parameters include pre-operative and post-operative assessment for stability of occlusion, mobility of fracture fragments, need for intermaxillary fixation (IMF), abnormality in wound healing/ soft tissue dehiscence.

\section{Radiological Parameters}

Orthopantomogram or Postero-anterior mandibular radiographs were taken for-

1. Displacement of Fracture Fragments- [Non-displaced, displaced $(<5 \mathrm{~mm})$, severely displaced $(>5 \mathrm{~mm})]$. In the post-operative radiographs, reductions were classified as adequate or inadequate.

2. Stability of Fixation- The alignment of the fracture fragments with continuity of the lower border of mandible was noted. Separation between the fracture fragments and change in the alignment of lower border was recorded as unstable fixation, if no change then it was recorded as stable fixation.

3. Healing of Fracture Site- Bone formation and fading of fracture line was recorded as present/ absent at the end of 6 months post-operatively.

\section{Statistical Analysis}

The parametric data are expressed as frequency and percentages. Non-parametric data is shown as proportions were compared using Chi-square test of significance. P value less than 0.05 were taken to be statistically significant. The data was analysed using SPSS software 21 version.

\section{RESULTS}

A total number of 19 patients with fractures in the mandible with or without associated fractures were treated in the Department of Dentistry. Out of 19 patients 13 (68.4\%) were male and 6 patients (31.6\%) were female patients, accounting for the gender ratio (M: F) of 2: 1 . The mean age was 30.2 years. Road traffic accident was the leading cause of injury in 15 patients (78.9\%) followed by self-fall in 4 patients $(21.1 \%)$.

The total number for sites of mandibular fracture in both the groups was 28 (13 fracture sites in Group-I and 15 fracture sites in Group-II). The most common site of the fracture was parasymphysis $(40.7 \%)$ followed by angle (22.3\%), subcondyle (14.8\%), body $(11.1 \%)$ and symphysis (11.1\%). Patients with more than one fracture sites in the mandible in both the groups were as follows: 4 patients (44.4\%) in Group-I and 5 patients (50.0\%) in Group-II. Out of 19 patients, 3 patients in each group had additional fractures of the maxilla and zygomatico-maxillary complex.

In Group-I, 2 patients received a single plate in the parasymphysis region in $(15.3 \%)$; rest of the patients $(7$ patients) received two plates in the symphysis and parasymphysis region. All fractures at the angle region received a single plate at the superior border. Patients with additional fractures at the condylar region were managed with closed reduction.

In Group-II, all patients with fractures at symphysis/parasymphysis received 2 plates and those with fracture at the body, angle and condylar region received a single plate.

Comparison of stability of occlusion between the groups is shown in Table $1 ; 6$ patients $(66.7 \%)$ from Group-I showed unstable occlusion in the $1^{\text {st }}$ post-operative week and 3 patients (30\%) in Group-II showed unstable occlusion postoperatively, it is statistically not significant. All the patients showed stable occlusion after 6 weeks and 6 months postoperatively. Comparison of the mobility of fracture fragments between the groups is depicted in Table 2 . 
In the present study, 4 patients (44.4\%) from Group-I showed fracture mobility at the end of $1^{\text {st }}$ post-operative week, but none in Group-II showed fracture mobility $(p<0.05)$. In the subsequent followup period, there was no mobility of fracture fragment in both the groups.

The comparison of the need for IMF between the groups is shown in Table 3. Post-operative IMF was done in 6 patients (66.7\%) from Group-I. There was no significant statistical difference found between the two groups. Comparing the rates of abnormality in wound healing/ soft tissue dehiscence is shown in Table 4. There was absence of abnormality in wound healing and soft tissue dehiscence in both groups. Comparison of displacement of fracture fragments is shown in Table 5. In Group-I, 5 patients (55.6\%) had displaced fracture preoperatively and there was adequate reduction of the fracture in all the 9 patients $(100 \%)$ post-operatively. In Group-II, 9 patients had displaced fracture pre-operatively and there was adequate reduction of fracture in all the 10 patients $(100 \%)$ postoperatively ( $\mathrm{P}>0.05 \mathrm{NS}$ ).

Radiological comparison of stability of fixation is shown in Table 6. In Group-I one patient (11.1\%) had unstable fixation with separation of the fracture fragment after 1st post-operative week. In Group-II, post-operatively there was no separation of fracture fragment and no change in the lower border continuity in any of the radiographs. Radiological comparison of healing rate of fracture site is shown in Table 7. The fading of fracture line was present in all the fractures 6 months post-operatively in both the groups (P $>0.05$ NS). Figure 1 shows Intraoperative: Fixation with $2.5 \mathrm{~mm}$ Bioresorbable Plates and Screws. Figure 2 shows post-operative OPG- Bioresorbable Plates and Screws patients. Figure 3 shows Intraoperative: Fixation of fracture with $2.0 \mathrm{~mm}$ Titanium Miniplate and Screws. Figure 4 shows Post-Operative OPG- Titanium Miniplate and Screws.

\begin{tabular}{|c|c|c|c|c|c|c|}
\hline \multirow{2}{*}{ Visit } & \multirow{2}{*}{ Group } & \multicolumn{2}{|c|}{ Stability of Occlusion } & \multirow{2}{*}{ Total } & \multirow{2}{*}{$\begin{array}{c}\text { Chi-square } \\
\text { Value }\end{array}$} & \multirow{2}{*}{ 'p' value } \\
\hline & & Satisfactory & Deranged & & & \\
\hline \multirow{4}{*}{ Pre-op } & \multirow{2}{*}{ Group I } & 1 & 8 & 9 & \multirow{4}{*}{1.173} & \multirow{4}{*}{.279} \\
\hline & & $11.1 \%$ & $88.9 \%$ & $100.0 \%$ & & \\
\hline & \multirow{2}{*}{ Group II } & 0 & 10 & 10 & & \\
\hline & & $0 \%$ & $100.0 \%$ & $100.0 \%$ & & \\
\hline \multirow{4}{*}{ 1st week } & \multirow{2}{*}{ Group I } & 3 & 6 & 9 & \multirow{4}{*}{2.554} & \multirow{4}{*}{.110} \\
\hline & & $33.3 \%$ & $66.7 \%$ & $100.0 \%$ & & \\
\hline & \multirow{2}{*}{ Group II } & 7 & 3 & 10 & & \\
\hline & & $70.0 \%$ & $30.0 \%$ & $100.0 \%$ & & \\
\hline \multirow{4}{*}{6 weeks } & \multirow{2}{*}{-} & 9 & 0 & 9 & \multirow{4}{*}{-} & \\
\hline & & $100.0 \%$ & $0 \%$ & $100.0 \%$ & & \\
\hline & \multirow{2}{*}{ Group II } & 10 & 0 & 10 & & \\
\hline & & $100.0 \%$ & $0 \%$ & $100.0 \%$ & & \\
\hline \multirow{4}{*}{6 months } & \multirow{2}{*}{ Group I } & 9 & 0 & 9 & \multirow{4}{*}{-} & \\
\hline & & $100.0 \%$ & $0 \%$ & $100.0 \%$ & & \\
\hline & \multirow{2}{*}{ Group II } & 10 & 0 & 10 & & \\
\hline & & $100.0 \%$ & $0 \%$ & $100.0 \%$ & & \\
\hline
\end{tabular}

\begin{tabular}{|c|c|c|c|c|c|c|}
\hline \multirow{2}{*}{ Visit } & \multirow{2}{*}{ Group } & \multicolumn{2}{|c|}{ Mobility of Fracture Fragments } & \multirow{2}{*}{ Total } & \multirow{2}{*}{$\begin{array}{c}\text { Chi-square } \\
\text { Value }\end{array}$} & \multirow{2}{*}{ 'p' value } \\
\hline & & Absent & Present & & & \\
\hline \multirow{4}{*}{ Pre-op } & \multirow{2}{*}{ Group I } & 0 & 9 & 9 & \multirow{4}{*}{ - } & \multirow{4}{*}{-} \\
\hline & & $0 \%$ & $100.0 \%$ & $100.0 \%$ & & \\
\hline & \multirow{2}{*}{ Group II } & 0 & 10 & 10 & & \\
\hline & & $0 \%$ & $100.0 \%$ & $100.0 \%$ & & \\
\hline \multirow{4}{*}{ 1st week } & \multirow{2}{*}{ Group I } & 5 & 4 & 9 & \multirow{4}{*}{5.630} & \multirow{4}{*}{0.018} \\
\hline & & $55.6 \%$ & $44.4 \%$ & $100.0 \%$ & & \\
\hline & \multirow{2}{*}{ Group II } & 10 & 0 & 10 & & \\
\hline & & $100.0 \%$ & $0 \%$ & $100.0 \%$ & & \\
\hline \multirow{4}{*}{6 weeks } & \multirow{2}{*}{ Group I } & 9 & 0 & 9 & \multirow{4}{*}{ - } & \multirow{4}{*}{ - } \\
\hline & & $100.0 \%$ & $0 \%$ & $100.0 \%$ & & \\
\hline & \multirow{2}{*}{ Group II } & 10 & 0 & 10 & & \\
\hline & & $100.0 \%$ & $0 \%$ & $100.0 \%$ & & \\
\hline \multirow{4}{*}{6 months } & \multirow{2}{*}{ Group I } & 9 & 0 & 9 & \multirow{4}{*}{-} & \multirow{4}{*}{ - } \\
\hline & & $100.0 \%$ & $0 \%$ & $100.0 \%$ & & \\
\hline & \multirow{2}{*}{ Group II } & 10 & 0 & 10 & & \\
\hline & & $100.0 \%$ & $0 \%$ & $100.0 \%$ & & \\
\hline
\end{tabular}




\begin{tabular}{|c|c|c|c|c|c|}
\hline \multirow{2}{*}{ Group } & \multicolumn{2}{|c|}{ Need for IMF } & \multirow{2}{*}{ Total } & \multirow{2}{*}{$\begin{array}{c}\text { Chi-square } \\
\text { Value }\end{array}$} & \multirow{2}{*}{ 'p' value } \\
\hline & Required & Not Required & & & \\
\hline \multirow{2}{*}{ Group-I } & 6 & 3 & 9 & \multirow{6}{*}{2.554} & \multirow{6}{*}{0.110} \\
\hline & $66.7 \%$ & $33.3 \%$ & $100.0 \%$ & & \\
\hline \multirow{2}{*}{ Group-II } & 3 & 7 & 10 & & \\
\hline & $30.0 \%$ & $70.0 \%$ & $100.0 \%$ & & \\
\hline \multirow{2}{*}{ Total } & 9 & 10 & 19 & & \\
\hline & $47.4 \%$ & $52.6 \%$ & $100.0 \%$ & & \\
\hline
\end{tabular}

\begin{tabular}{|c|c|c|c|}
\hline Visit & Group & $\begin{array}{c}\text { Abnormality in } \\
\text { Wound Healing/ } \\
\text { Soft Tissue Dehiscence }\end{array}$ & Total \\
\hline & & Absent & \\
\hline \multirow{4}{*}{ 1st week } & \multirow{2}{*}{ Group I } & 9 & 9 \\
\hline & & $100.0 \%$ & $100.0 \%$ \\
\hline & \multirow{2}{*}{ Group II } & 10 & 10 \\
\hline & & $100.0 \%$ & $100.0 \%$ \\
\hline \multirow{4}{*}{6 weeks } & \multirow{2}{*}{ Group I } & 9 & 9 \\
\hline & & $100.0 \%$ & $100.0 \%$ \\
\hline & \multirow{2}{*}{ Group II } & 10 & 10 \\
\hline & & $100.0 \%$ & $100.0 \%$ \\
\hline \multirow{4}{*}{6 months } & \multirow{2}{*}{ Group I } & 9 & 9 \\
\hline & & $100.0 \%$ & $100.0 \%$ \\
\hline & \multirow{2}{*}{ Group II } & 10 & 10 \\
\hline & & $100.0 \%$ & $100.0 \%$ \\
\hline
\end{tabular}

\begin{tabular}{|c|c|c|c|c|c|c|c|}
\hline \multirow[b]{2}{*}{ Visit } & \multirow[b]{2}{*}{ Group } & \multicolumn{3}{|c|}{ Displacement of Fracture Fragments } & \multirow[b]{2}{*}{ Total } & \multirow{2}{*}{$\begin{array}{c}\text { Chi-square } \\
\text { Value }\end{array}$} & \multirow[b]{2}{*}{ 'p' value } \\
\hline & & $\begin{array}{l}\text { Adequate } \\
\text { Reduction }\end{array}$ & Displaced & Non-Displaced & & & \\
\hline \multirow{4}{*}{ Pre-op } & \multirow{2}{*}{ Group I } & 0 & 5 & 4 & 9 & \multirow{4}{*}{2.898} & \multirow{4}{*}{.089} \\
\hline & & $0 \%$ & $55.6 \%$ & $44.4 \%$ & $100.0 \%$ & & \\
\hline & \multirow{2}{*}{ Group II } & 0 & 9 & 1 & 10 & & \\
\hline & & $0 \%$ & $90.0 \%$ & $10.0 \%$ & $100.0 \%$ & & \\
\hline \multirow{7}{*}{ 1st week } & \multirow{2}{*}{ Group I } & 9 & 0 & 0 & 9 & & \\
\hline & & $100.0 \%$ & $0 \%$ & $0 \%$ & $100.0 \%$ & & \\
\hline & \multirow{3}{*}{ Group II } & 10 & 0 & 0 & 10 & & \\
\hline & & $100.0 \%$ & $0 \%$ & $0 \%$ & $100.0 \%$ & & \\
\hline & & $100.0 \%$ & $0 \%$ & $0 \%$ & $100.0 \%$ & & \\
\hline & \multirow{2}{*}{ Group II } & 10 & 0 & 0 & 10 & & \\
\hline & & $100.0 \%$ & $0 \%$ & $0 \%$ & $100.0 \%$ & & \\
\hline & & Table 5. Com & of Displc & nt of Fracture $F$ & gments & & \\
\hline
\end{tabular}

\begin{tabular}{|c|c|c|c|c|c|c|}
\hline \multirow{2}{*}{ Visit } & \multirow{2}{*}{ Group } & \multicolumn{2}{|c|}{ Stability of Fixation } & \multirow{2}{*}{ Total } & \multirow{2}{*}{$\begin{array}{c}\text { Chi-Square } \\
\text { Value }\end{array}$} & \multirow{2}{*}{ 'p' value } \\
\hline & & Stable & Unstable & & & \\
\hline \multirow{4}{*}{ 1st week } & \multirow{2}{*}{ Group I } & 8 & 1 & 9 & \multirow{4}{*}{1.173} & \multirow{4}{*}{.279} \\
\hline & & $88.89 \%$ & $11.1 \%$ & $100.0 \%$ & & \\
\hline & \multirow{2}{*}{ Group II } & 10 & 0 & 10 & & \\
\hline & & $100.0 \%$ & $0 \%$ & $100.0 \%$ & & \\
\hline \multirow{4}{*}{6 weeks } & \multirow{2}{*}{ Group I } & 9 & 0 & 9 & \multirow{4}{*}{ - } & \multirow{4}{*}{-} \\
\hline & & $100.0 \%$ & $0 \%$ & $100.0 \%$ & & \\
\hline & \multirow{2}{*}{ Group II } & 10 & 0 & 10 & & \\
\hline & & $100.0 \%$ & $0 \%$ & $100.0 \%$ & & \\
\hline \multirow{4}{*}{6 months } & \multirow{2}{*}{ Group I } & 9 & 0 & 9 & \multirow{4}{*}{ - } & \multirow{4}{*}{-} \\
\hline & & $100.0 \%$ & $0 \%$ & $100.0 \%$ & & \\
\hline & \multirow{2}{*}{ Group II } & 10 & 0 & 10 & & \\
\hline & & $100.0 \%$ & $0 \%$ & $100.0 \%$ & & \\
\hline
\end{tabular}




\begin{tabular}{|c|c|c|c|}
\hline \multirow{2}{*}{ Visit } & \multirow{2}{*}{ Group } & Healing of Fracture Site & \multirow{2}{*}{ Total } \\
\hline & & Present & \\
\hline \multirow{6}{*}{6 months } & \multirow{2}{*}{ Group I } & 9 & 9 \\
\hline & & $100.0 \%$ & $100.0 \%$ \\
\hline & \multirow{2}{*}{ Group II } & 10 & 10 \\
\hline & & $100.0 \%$ & $100.0 \%$ \\
\hline & \multirow{2}{*}{ Total } & 19 & 19 \\
\hline & & $100.0 \%$ & $100.0 \%$ \\
\hline
\end{tabular}

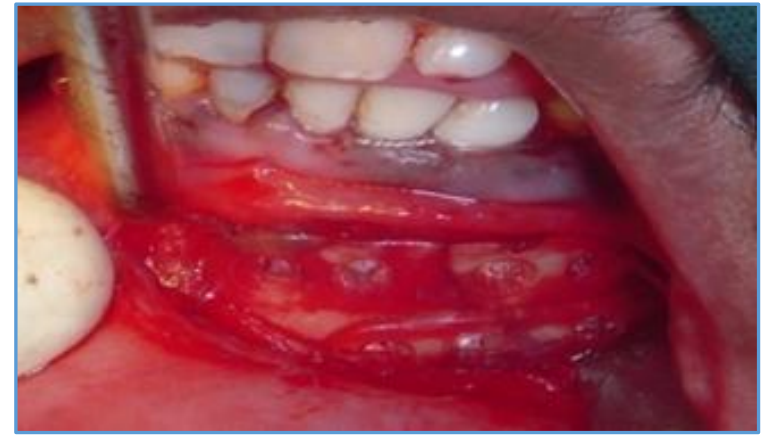

Figure 1. Intraoperative: Fixation with $2.5 \mathrm{~mm}$ Bioresorbable Plates and Screws

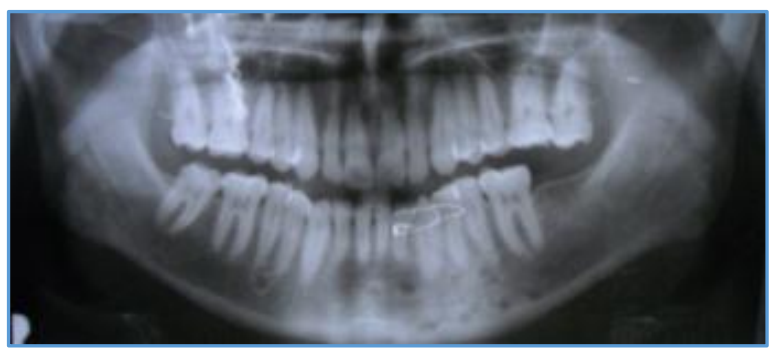

Figure 2. Post-Operative OPG-Bioresorbable Plates and Screws Patients

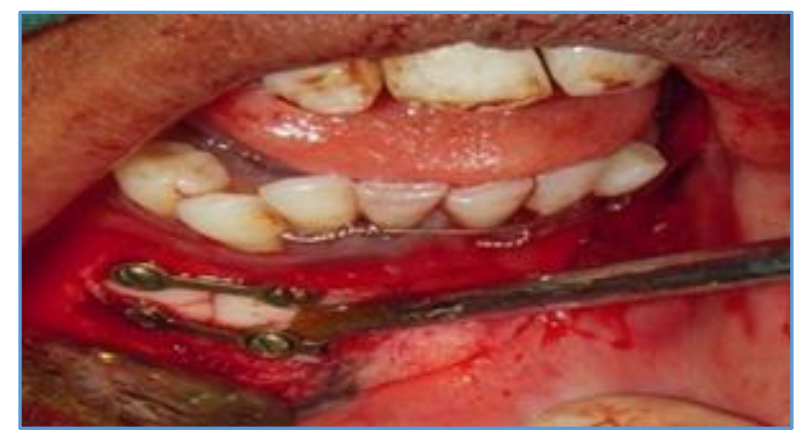

Figure 3. Intraoperative: Fixation of Fracture with $2.0 \mathrm{~mm}$ Titanium Miniplate and Screws

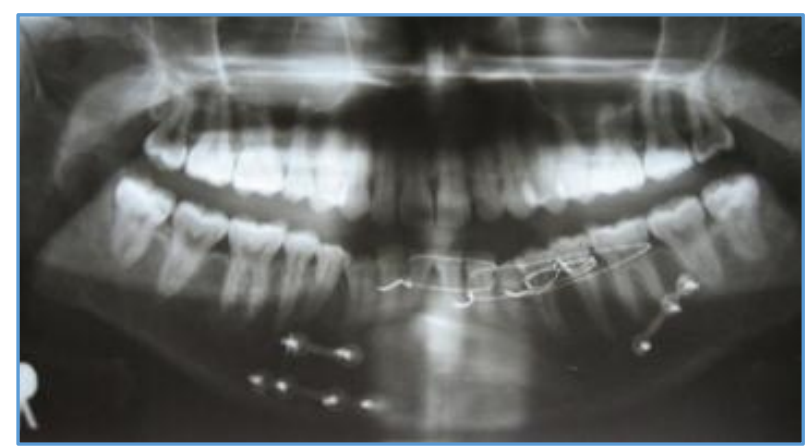

Figure 4. Post-Operative OPG- Titanium Miniplate and Screws

\section{DISCUSSION}

Internal fixation using titanium plates and screws in craniomaxillofacial surgery is regarded as the "gold standard." However, studies have reported problems with titanium fixation, which have warranted the removal of titanium plates and screws after the consolidation of bone segments. These include thermal conductivity, palpability, allergic hypersensitivity, infection around the plates, growth restriction and plate translocation. ${ }^{7}$

The use of bioresorbable plates and screws is an alternative to titanium plates and screws. ${ }^{8}$ The bioresorbable plates and screws gradually transfer load to the healing bone as they resorb. Stress shielding and osteopenia seen with metal implants are rarely seen with the bioresorbable plates and screws. ${ }^{9}$ Our study enrolled 19 patients over a period of 1 year. The gender ratio of occurrence of the mandibular fractures is 2: 1, similar to the studies by Gabrielli et al and Pedersen et al.10,11 The main cause for mandibular fracture was road traffic accident followed by self-fall, which is in accordance with other studies by Gabrielli et al.10

In a study by Laughlin et al,12 the most common site of the fracture was angle followed by parasymphysis, body and symphysis which is in contrast to our study where the most common site of the facture was parasymphysis $(40.7 \%)$ followed by angle (22.3\%) and subcondylar fracture (14.8\%), body and symphysis region (11.1\%) each.

In the present study, there were twice as many as deranged occlusion in the 1 st post-operative week in Group-I when compared to Group-II, in which more than half the patients had satisfactory occlusion in the 1 st post-operative week. In our study, disturbances of occlusion were treated by intermaxillary traction for 1 week for 5 patients and intermaxillary fixation for three weeks in 1 patient in Group I, whereas in Group-II intermaxillary traction was applied in 3 patients for a week. There were no occlusal problems in both the groups after 6 weeks and 6 months post-operatively. This is in accordance to study done by Bhatt et al. ${ }^{13}$

In the present study, the mobility of fracture fragment at the end of $1^{\text {st }}$ week of post-operative period in Group-I was found in 4 patients (44.4\%), whereas there was no mobility of the fracture fragments after 6 weeks and 6 months postoperatively. In Group-II, there was no mobility of the fracture fragments post-operatively. Our study results are in accordance with Cheung et al, wherein the stability of the osteotomised segments were found to improve gradually overtime and there was no difference between the resorbable and titanium fixation. ${ }^{7}$

In our study, there was no abnormality in wound healing and soft tissue dehiscence in both groups. This is in accordance with the study by Yerit et $\mathrm{al}^{9}$ and in contrast with the study done by Leonhardt et al in which they found wound dehiscence and haematoma in both the groups in equal number.9,14 Radiographically, there was no difference in the 
percentage of displaced fractures in both the groups preoperatively. In the post-operative radiographs, all the fractures in both the groups had adequate reduction. This is in accordance with the study by Kallela et al. ${ }^{15}$

\section{CONCLUSION}

We observed that the bioresorbable plates provide better occlusion stability and reduces the need for IMF in nondisplaced fractures. In those patients with displaced fractures not associated with additional fracture of the facial skeleton, titanium miniplates $(2.0 \mathrm{~mm})$ showed more favourable results compared to bioresorbable plates in terms of parameters occlusion stability, need for IMF, fracture mobility, fixation stability. With regard to this particular study, it can be concluded that use of $2.0 \mathrm{~mm}$ titanium miniplate is a viable and better option for fixation of mandibular fractures. At the end of 1 week of post-operative period, titanium plates significantly allows early masticatory functions compared to bioresorbable plates.

\section{REFERENCES}

[1] Fonseca RJ, Walker RV. Oral and Maxillofacial trauma. Vol 1. $3^{\text {rd }}$ edn. Philadelphia: WB Saunders Company 1997.

[2] Williams JL. Rowe and Williams Maxillofacial injuries. Vol 2. $2^{\text {nd }}$ edn. Edinburgh: Elsevier/Churchill Livingstone 1994.

[3] Booth P. Maxillofacial surgery. Vol 1. $2^{\text {nd }}$ edn. Churchill Livingstone 2006.

[4] Menon S, Chowdhury SKR. Evaluation of bioresorbable vis - a - vis titanium plates and screws for craniofacial fractures and osteotomies. Medical Journal Armed Forces India 2007;63(4):331-3.

[5] Wood GD. Inion biodegradable plates: the first century. British Journal of Oral and Maxillofacial Surgery 2006;44(1):38-41.

[6] Landes CA, Kriener S, Menzer M, et al. Resorbable plate osteosynthesis of dislocated or pathological mandibular fractures: a prospective clinical trial of two amorphous L-/DL-lactide copolymer 2-mm miniplate systems. Plastic and Reconstructive Surgery 2003;111(2):601-10.
[7] Cheung LK, Chow LK, Chiu WK. A randomized controlled trial of resorbable versus titanium fixation for orthognathic surgery. Oral Surg Oral Med Oral Pathol Oral Radiol Endod 2004;98(4):386-97.

[8] Vaananen P, Nurmi JT, Nuutine JP, et al. Fixation properties of a biodegradable "free-form" osteosynthesis plate. Oral Surg Oral Med Oral Pathol Oral Radiol Endod 2008;106(4):477-82.

[9] Yerit KC, Enislidis G, Schopper C, et al. Fixation of mandibular fractures with biodegradable plates and screws. Oral Surg Oral Med Oral Pathol Oral Radiol Endod 2002;94(3):294-300.

[10] Gabrielli CMA, Gabrielli RMF, Marcantonio E, et al. Fixation of mandibular fractures with $2.0 \mathrm{~mm}$ miniplates: review of 191 cases. J Oral Maxillofacial Surgery 2003;61(4):430-6.

[11] Tuovinen V, Norholt SE, Sindet-Pedersen S, et al. A retrospective analysis of 279 patients with isolated mandibular fractures treated with titanium miniplates. J Oral Maxillofac Surg 1994;52(9):931-6.

[12] Laughlin RM, Block MS, Wilk R, et al. Resorbable plates for fixation of mandibular fractures: a prospective study. J Oral Maxillofac Surg 2007;65(1):89-96.

[13] Bhatt K, Roychoudhury A, Bhutia 0, et al. Equivalence randomized controlled trial of bioresorbable versus titanium miniplates in treatment of mandibular fracture: a pilot study. J Oral Maxillofac Surg 2010;68(8):1842-8.

[14] Leonhardt H, Demmrich A, Mueller A, et al. INION compared with titanium osteosynthesis: a prospective investigation of the treatment of mandibular fractures. British Journal of Oral and Maxillofacial Surgery 2008;46:631-4.

[15] Kallela I, Iizuka T, Salo A, et al. Lag-screw fixation of anterior mandibular fractures using biodegradable polylactide screws: a preliminary report. J Oral Maxillofac Surg 1999;57(2):113-8. 